\title{
ANALISIS PENGARUH FAKTOR-FAKTOR PRODUKSI TERHADAP PRODUKSI PADI ANGGOTA KELOMPOK TANI MARGO UTOMO KECAMATAN UNGARAN TIMUR KABUPATEN SEMARANG
}

\author{
Analysis of Production Factors Affecting the Rice Production at Margo Utomo \\ Farmer Group Members in Ungaran Timur Sub-District of Semarang District
}

\author{
M. S. Hutahaean ${ }^{1)}$, B. M. Setiawan ${ }^{\text {() }}$, E. Prasetyo ${ }^{1)}$ \\ ${ }^{1)}$ Program Studi Agribisnis Fakultas Peternakan dan Pertanian Universitas Diponegoro \\ Email: melatihutahaean30@gmail.com \\ Email: b_mulyatno@yahoo.co.id. Email: edyprsty@yahoo.com.
}

\begin{abstract}
This study aimed to analyze the effect of utilizing production factors on rice production and to analyze the level of economic efficiency and technical efficiency of using production factors in rice farming system of the members of the Margo Utomo farmer group in Kalikayen village, Ungaran Timur sub-district, Semarang district. This research was conducted in November December 2018 and the location was determined purposively in Kalikayen village, Ungaran Timur sub-district, Semarang district. Determination of samples in this study used the census method. Data was collected from all members of the Margo Utomo farmer group of 50 respondents by interviews using questionnaires. The data was analyzed using the multiple linear regression analysis method which than transformed into the Cobb-Douglas model production function and using one sample t-test to find the technical efficiency and the economic efficiency. The results showed that the use of production factors of land, seed, urea fertilizer had significant effect on the rice yield while the production factors of labor and pesticide had no effect. The use of factors such as land, labor, seed, urea fertilizer and pesticide was technically inefficient. The use of production factors such as land, seed, and urea fertilizer was not yet economically efficient while labor and pesticide was economically inefficient.
\end{abstract}

Keywords : Efficiency, Factors Of Production, and Rice Production.

\begin{abstract}
ABSTRAK
Penelitian ini bertujuan untuk menganalisis pengaruh penggunaan faktor-faktor produksi terhadap produksi padi dan menganalisis tingkat efisiensi teknis dan efisiensi ekonomis penggunaan faktor-faktor produksi pada usahatani padi di anggota Kelompok Tani Margo Utomo Desa Kalikayen Kecamatan Ungaran Timur Kabupaten Semarang. Penelitian ini dilaksanakan pada bulan November - Desember 2018 di Kelompok Tani Margo Utomo Desa Kalikayen Kecamatan Ungaran Timur Kabupaten Semarang. Penentuan lokasi ditentukan secara sengaja (purposive). Metode penelitian dan penentuan sampel dalam penelitian ini yaitu dengan metode sensus. Teknik pengumpulan data pada penelitian ini dari hasil wawancara menggunakan alat bantu kuesioner dengan seluruh anggota Kelompok Tani Margo Utomo yaitu 50 Responden. Metode analisis data menggunakan metode analisis linier regresi berganda yang ditransformasi kedalam fungsi produksi model Cobb-Douglas dan analisis efisiensi teknis serta efisiensi ekonomis yang diuji menggunakan analisis uji beda (one sample $T$ test). Hasil penelitian menunjukan bahwa penggunaan faktor produksi luas lahan, benih dan pupuk urea berpengaruh nyata terhadap hasil produksi sedangkan faktor produksi tenaga kerja dan pestisida tidak berpengaruh nyata terhadap hasil produksi. Penggunaan faktor produksi luas lahan, tenaga kerja, benih, pupuk urea dan pestisida tidak efisien secara teknis. Faktor produksi luas lahan, benih, pupuk urea belum efisien secara ekonomis sedangkan faktor produksi tenaga kerja dan pestisida tidak efisien secara ekonomis.
\end{abstract}

Kata Kunci : Efisiensi, Faktor-Faktor Produksi, dan Produksi Padi. 


\section{PENDAHULUAN}

Tanaman padi (Oryza sativa L.) bagi masyarakat Indonesia merupakan tanaman pangan yang perannya sangat penting bagi kebutuhan primer masyarakat, karena hasil produksi padi yaitu beras merupakan makanan pokok masyarakat Indonesia (Baptista, Damanhuri,\& Nunun Barunawati, 2018; Indrasumunar et al., 2011) Populasi penduduk di Indonesia yang semakin tahun semakin meningkat menjadikan kebutuhan akan beras juga semakin meningkat, untuk itu stok beras harus terus tercukupi sehingga tidak perlu melakukan impor (Huo et al., 2017; Zeigler \& Barclay, 2008)

Kecamatan Ungaran Timur mempunyai potensi dibidang pertanian, khususnya tanaman padi. Luas panen tanaman padi Kecamatan Ungaran Timur menduduki peringkat ke 14 dari 19 kecamatan yang ada di Kabupaten Semarang yaitu termasuk dalam kategori rendah. Produksi padi di Kecamatan Ungaran Timur mengalami fluktuasi yang selalu naik dan turun. Tahun 2013 produksi padi sawah di Kecamatan Ungaran Timur sebesar 6.674,29 ton dari luas lahan sebesar 1.285 ha dengan produktivitas $51,94 \mathrm{kw} / \mathrm{ha}$, kemudian di tahun 2014 produksi padi sawah meningkat sebesar $6.961,45$ ton dan luas lahan sebesar 1.271 ha dengan produktivitas $54,77 \mathrm{kw} / \mathrm{ha}$, serta di tahun 2015 produksi padi mengalami penurunan sebesar $6.388,00$ ton dan luas lahan 1.208 ha dengan produktivitas 52,88 $\mathrm{kw} / \mathrm{ha}$ (Badan Pusat Statistika, 2017). Produksi utama di Desa Kalikayen yaitu padi sawah, mempunyai luas lahan pertanian sawah terbesar nomor 4 di Kecamatan Ungaran Timur dengan 109,72 ha (Badan Pusat Statistika, 2018). Desa Kalikayen terdapat beberapa kelompok tani, salah satu kelompok taninya yaitu Kelompok Tani Margo Utomo. Kelompok Tani Margo Utomo berdiri sejak tahun 1985, mempunyai karakteristik yaitu aktif dalam peran pemberdayaan petani dan mempunyai potensi dalam produksi padi, tetapi masih terdapat petani yang kurang pengetahuan dan teknologi untuk mengelola pertanian secara maksimal. Komoditas yang dibudidayakan dan diproduksi oleh Kelompok Tani Margo Utomo salah satunya yaitu padi.

Penurunan produksi dan produktivitas tahun 2015 membuat petani rugi, maka dari itu perlu diketahui penyebab terjadinya penurunan produksi. Produksi padi dapat dipengaruhi oleh beberapa faktor produksi yaitu luas lahan, penggunaan benih, pestisida dan pupuk serta pencurahan tenaga kerja (Aprillya, Suryani, \& Dzulkarnain, 2019; Bashir \&Yuliana, 2019). Penggunaan input produksiapabila sudah optimal akan meningkat produksi padi maka dari itu petani perlu memahami cara mengelola input produksi padi sehingga hasil produk padi dapat sesuai dengan yang di harapkan oleh petani (Karmini, 2017; Ramachandra Reddy \& Kishori, 2019)

Tujuan dari penelitian yaitu menganalisis pengaruh penggunaan faktor produksi luas lahan, tenaga kerja, benih, pupuk urea dan pestisida terhadap produksi padi dan menganalisis tingkat efisiensi teknis dan efisiensi ekonomi penggunaan faktor produksi luas lahan, tenaga kerja, benih, pupuk urea dan pestisida pada usahatani padi di anggota Kelompok Tani Margo Utomo Desa Kalikayen Kecamatan Ungaran Timur Kabupaten Semarang.

\section{METODE PENELITIAN}

Penelitian dilakukan pada bulan November-Desember 2018 di anggota Kelompok Tani Mago Utomo, Desa Kalikayen, Kecamatan Ungaran Timur, Kabupaten Semarang. Pemilihan lokasi penelitian ditentukan secara sengaja (purposive) berdasarkan pertimbangan bahwa lokasi tersebut merupakan daerah yang sudah berkembang dalam memproduksi padi dan merupakan desa yang aktif dalam pemberdayaan petani.

Metode penelitian yang digunakan dalam penelitian yaitu dengan metode 
sensus (Banerjee \& Chaudhury, 2010; Panel on Reengineering the Census Bureau's Annual Economic Surveys, Committee on National Statistics, Division of Behavioral and Social Sciences and Education, \& National Academies of Sciences, Engineering, and Medicine, 2018) Metode sensus atau sampel total (total sampling) adalah cara pengambilan sampel menggunakan seluruh anggota populasi. Responden yang digunakan pada penelitian yaitu seluruh anggota Kelompok Tani Margo Utomo yang berjumlah 50 orang petani padi.

Data yang dikumpulkan pada penelitian ini adalah data primer dan data sekunder. Data primer diperoleh dari hasil wawancara dengan petani menggunakan alat bantu berupa kuesioner yang berisi tentang identitas responden, penggunaan luas lahan, tenaga kerja, benih, pupuk, pestisida dan produksi padi. Data sekunder diperoleh dari jurnal, laporan, skripsi serta pustaka lain yang berhubungan dengan penelitian ini dan dari instansi terkait seperti hasil produksi padi, luas lahan padi sawah, produktivitas padi di Kecamatan Ungaran Timur, Desa Kalikayen.

Tujuan pertama dengan hipotesis pertama menggunakan analisis regresi linier berganda yang ditransformasi kedalam fungsi produksi model Cobb-Douglas (Basegmez\& Onalan, 2018; Berndt \& Christensen, 1973). Fungsi tersebut dalam persamaan sebagai berikut:

$\mathrm{Y}=\mathrm{a} \mathrm{X}_{1}{ }^{\mathrm{b} 1} \mathrm{X}_{2}{ }^{\mathrm{b} 2} \mathrm{X}_{3}{ }^{\mathrm{b} 3} \mathrm{X}_{4}{ }^{\mathrm{b} 4} \mathrm{X}_{5}{ }^{\mathrm{b} 5} \mathrm{e}^{\mathrm{u}}$

Keterangan:

$\mathrm{Y} \quad=$ produksi padi $(\mathrm{kg} / \mathrm{panen})$

$\mathrm{a} \quad=$ konstanta

$\mathrm{X}_{1} \quad=$ luas lahan $\left(\mathrm{m}^{2} /\right.$ panen $)$

$\mathrm{X}_{2} \quad=$ tenaga kerja $(\mathrm{HOK} /$ panen $)$

$\mathrm{X}_{3} \quad=$ jumlah benih $(\mathrm{kg} /$ panen $)$

$\mathrm{X}_{4} \quad=$ jumlah pupuk urea $(\mathrm{kg} / \mathrm{panen})$

$\mathrm{X}_{5} \quad=$ jumlah pestisida (liter/panen)

$\mathrm{e} \quad=$ bilangan natural $(2,718)$

$\mathrm{u} \quad=$ error/kesalahan

b1-b5 =koefisien regresi dari masingmasing input produksi

Fungsi produksi diatas kemudian ditrasformasikan kedalam bentuk linier logaritma untuk mempermudah pendugaan terhadap fungsi produksi, sehingga dapat persamaan sebagai berikut:

$$
\begin{aligned}
\mathrm{LnY}= & \ln \mathrm{a}+\mathrm{b} 1 \ln \mathrm{X}_{1}+\mathrm{b} 2 \ln \mathrm{X}_{2}+\mathrm{b} 3 \ln \mathrm{X}_{3} \\
& +\mathrm{b} 4 \ln \mathrm{X}_{4}+\mathrm{b} 5 \ln \mathrm{X}_{5}+\mathrm{u}
\end{aligned}
$$

Berdasarkan hasil pengumpulan data lapang maka diperoleh data empiris yang selanjutnya ditabulasi dan diuji normalitas serta uji asumsi klasik. Uji normalitas merupakan pengujian data dari sampel untuk mengetahui apakah data berdistribusi normal atautidak. Jenis uji normalitas yang digunakan pada penelitian ini yaitu uji Kolmogorov-Smirnov. Uji asumsi klasik merupakan pengujian asumsi statistik yang harus terpenuhi pada analisis regresi linier berganda yang berbasis ordinary least square (OLS) (Meier, Eilola, \& Almroth, 2011; Peprah \& Mensah, 2017) Perlu menguji asumsi klasik untuk mengetahui apakah hasil regresi yang dilakukan benar bebas dari gejala multikolinearitas, gejala auto korelasi dan gejala heteroskedastisitas.

Uji $F$ untuk menguji apakah input produksi $\mathrm{X}$ secara serempak berpengaruh terhadap hasil produksi padi (Y) dan uji t untuk menguji apakah input produksi $\mathrm{X}$ secara parsial berpengaruh terhadap hasil produksi padi (Y).

Tujuan kedua dengan hipotesis kedua menggunakan perhitungan efisiensi teknis dan efisiensi ekonomis dan di uji menggunakan analisis uji beda (one sample $t$ test) (Kim, 2015; Rahardja,2017). Efisiensi teknis merupakan suatu proses faktor-faktor produksi untuk menghasilkan produksi yang maksimal (Alamsyah, 2017). Efisiensi ekonomi merupakan suatu tingkat perbandingan antara keuntungan yang sebenarnya dengan keuntungan yang maksimum.

Tingkat efisiensi teknis dan efisiensi ekonomi penggunaan faktor-faktor produksi pada usahatani padi dapat dihitung menggunakan rumus elastisitas produksi (Ekowati et al., 2014) sebagai berikut:

$\mathrm{ET}=\frac{\text { MPPxi }}{\text { APPxi }}=\mathrm{Bxi}$ 
Keterangan:

APPxi : produksi rata-rata faktor produksi ke i

MPPxi : produksi marjinal faktor produksi ke i

Bxi : elastisitas produksi xi

Kriteria:

ET $=1$ : penggunaan faktor produksi efisien

ET $>1$ : penggunaan faktor produksi belum efisien

ET $<1$ : penggunaan faktor produksi tidak efisien

$\mathrm{EE}=\frac{\mathrm{NPMxi}}{\mathrm{BKMxi}}=\frac{\text { MPP } . \text { Py }}{\text { Pxi }}$

Keterangan:

NPMxi : Nilai Produk Marjinal faktor produksi ke i

BKMxi : Biaya Korbanan Marjinal faktor produksi ke i

MPPxi : produksi marjinal faktor produksi ke i

Py $\quad$ : Harga produk $(\mathrm{Rp})$

Pxi : Harga rata-rata masing-masing faktor produksi (Rp)

Efisiensi ekonomi diuji menggunakan one sample $T$ test (nilai test $=1$ ), hipotesisinya sebagai berikut:

$\mathrm{H}_{0}=\frac{\text { NPMxi }}{\text { BKMxi }}=1$

$\mathrm{H}_{1}=\frac{\mathrm{NPMxi}}{\mathrm{BKMxi}} \neq 1$

Kriteria :

1. $\mathrm{H}_{0}$ ditolak dan $\mathrm{H}_{1}$ diterima apabila nilai signifikansi $\leq 0,05$

2. $\mathrm{H}_{0}$ diterima dan $\mathrm{H}_{1}$ ditolak apabila nilai signifikansi $>0,05$

3. $\mathrm{NPM} / \mathrm{BKM}=1$ artinya efisiensi ekonomis tercapai

4. NPM/BKM > 1 artinya efisiensi ekonomis belum tercapai

5. NPM/BKM $<1$ artinya efisiensi ekonomis tidak tercapai

\section{HASIL DAN PEMBAHASAN}

Karakteristik Responden. Responden dalam penelitian ini semua anggota Kelompok Tani Margo Utomo, Desa Kalikayen, Kecamatan Ungaran Timur,
Kabupaten Semarang dengan jumlah responden sebanyak 50 petani. Karakteristik responden dapat menjadi gambaran umum petani yang dibahas berdasarkan umur, pendidikan dan lama bertani.

Berdasarkan Tabel 1. diatas diperoleh hasil bahwa umur anggota Kelompok Tani Margo Utomo terbanyak berada di umur 51-60 tahun sebanyak 21 orang $(42 \%)$ dan yang paling sedikit umur 31-40 tahun dan umur 71-80 tahun sebanyak masing-masing 2 orang (4\%). Lama bertani terbanyak yaitu 31-40 tahun sebanyak $14(28 \%)$ dan yang paling sedikit 51-60 bertani sebanyak 1 orang (2\%). Pendidikan yang terbanyak ditingkat SD 43 orang (86\%), selanjutnya tingkat SMA sebanyak 4 orang $(8 \%)$ dan yang paling sedikit yaitu tingkat SMP sebanyak 3 orang (6\%), Untuk lebih jelas terlihat pada Tabel 1.

\section{Pengaruh Penggunaan Faktor-Faktor Produksi Terhadap Produksi Padi. Data} faktor produksi yang diolah yaitu luas lahan yang diukur dalam satuan meter $^{2}$, tenaga kerja diukur dalam satuan hari orang kerja (HOK), benih yang diukur dalam satuan kilogram, pupuk urea yang diukur dalam satuan kilogram dan pestisida yang diukur dalam satuan mililiter. Berdasarkan hasil analisis regresi linear ditulis dengan fungsi produksi model Cobb-Douglas dalam bentuk logaritma natural sebagai berikut:

Ln $Y=1,645+0,531 \ln X_{1}+0,046 \ln X_{2}$ $+0,246 \ln X_{3}+0,179 \ln X_{4}-0,028$ $\ln \mathrm{X}_{5}$

Berdasarkan hasil yang diperoleh bahwa nilai koefisien determinasi $\left(\mathrm{R}^{2}\right)$ yaitu sebesar 0,967 atau $96,7 \%$ yang artinya bahwa 96,7\% variabel independen mampu menjelaskan variabel dependen dan sisanya sebesar 3,3\% dijelaskan oleh variabel lain diluar yang diteliti. Berarti penggunaan kelima faktor-faktor produksi dapat mengestimasi produksi padi dengan baik.

Pengaruh penggunaan faktor-faktor produksi secara bersama-sama (serempak) terhadap produksi padi menggunakan uji $\mathrm{F}$ dengan tingkat signifikan 0,05 , seperti tertera pada Tabel 2. 


\begin{tabular}{ccc}
\multicolumn{2}{l}{ Tabel 1. Jumlah dan Persentase Karakteristik Responden } & \\
\hline Karakteristik Responden & Jumlah (orang) & Persentase (\%) \\
\hline Umur (tahun) & 2 & 4 \\
$31-40$ & 10 & 20 \\
$41-50$ & 21 & 42 \\
$51-60$ & 15 & 30 \\
$61-70$ & 2 & 4 \\
$71-80$ & & 22 \\
Lama bertani & 11 & 22 \\
$11-20$ & 11 & 28 \\
$21-30$ & 14 & 26 \\
$31-40$ & 13 & 2 \\
$41-50$ & 1 & 86 \\
$51-60$ & & 6 \\
Pendidikan & 43 & 8 \\
SD & 3 & \\
SMP & 4 & \\
SMA & & \\
& & \\
\hline
\end{tabular}

Sumber: Data Primer Penelitian, 2018.

Tabel 2. Hasil Analisis Uji F

\begin{tabular}{crrrrc}
\hline Model & Sum of Squares & \multicolumn{1}{c}{ Df } & Mean Square & F & \multicolumn{1}{c}{ Sig. } \\
\hline Regression & 18,832 & 5 & 3,766 & 292,271 & 0,000 \\
Residual & 0,567 & 44 & 0,013 & & \\
Total & 19,399 & 49 & & & \\
\hline
\end{tabular}

Sumber: Data Primer Penelitian, 2018.

Berdasarkan Tabel 2. dapat diketahui bahwa nilai signifikansi sebesar 0,000 lebih kecil dari nilai alpha yaitu 0,05 maka dari itu $\mathrm{H}_{\mathrm{o}}$ ditolak dan $\mathrm{H}_{1}$ diterima, sehingga dapat disimpulkan bahwa variabel independen meliputi luas lahan, tenaga kerja, benih, pupuk urea dan pestisida bersama-sama secara serempak berpengaruh terhadap variabel dependen yaitu hasil produksi padi.

Uji $t$ untuk menguji pengaruh faktor-faktor produksi secara parsial terhadap hasil produksi padi. Setiap variabel independen diuji masing-masing dengan tingkat signifikansi yaitu sebesar 0,05, seperti tertera pada Tabel 3.

Berdasarkan Tabel 3. diperoleh hasil analisis uji t yaitu variabel luas lahan, benih dan pupuk urea memiliki nilai signifikansi sebesar lebih kecil dari 0,05 (alpha $=5 \%)$ yang artinya bahwa variabel luas lahan, benih dan pupuk urea berpengaruh nyata terhadap variabel produksi padi. Variabel tenaga kerja dan pestisida memiliki nilai lebih besar dari 0,05 (alpha $=5 \%$ ) yang artinya bahwa variabel tenaga kerja dan pestisida berpengaruh tidak nyata terhadap variabel produksi padi.

Variabel luas lahan berpengaruh nyata terhadap variabel produksi padi dengan nilai signifikan lebih kecil dari nilai alpha $(0,000<0,05)$ (Fitri, Mustafa, \& Azhar, 2018; Laghi-Pasini, 1977). Luas lahan merupakan faktor produksi yang berpengaruh paling besar terhadap produksi padi di Kelompok Tani Margo Utomo (Kanianska, 2016; Liu, Bruins, \& 
Heberling, 2018) Luas lahan sangat penting dalam proses usahatani padi karena mempunyai kontribusi yang besar, adanya lahan dapat menghasilkan suatu produk padi, makin luas lahan yang digunakan petani maka makin banyak produksi yang dihasilkan petani. Hal ini sesuai dengan penelitian Yuliana et al. (2017) yang menyatakan bahwa penggunaan faktor produksi luas lahan berpengaruh nyata terhadap produksi padi dengan nilai signifikansi sebesar 0,000 . Hal ini sesuai dengan pendapat Khazanani (2011) yang menyatakan bahwa produksi dari usahatani dipengaruhi oleh luas dan sempitnya lahan yang digunakan oleh petani.

Variabel tenaga kerja berpengaruh tidak nyata terhadap variabel produksi padi dilihat dari nilai signifikansi yang lebih besar dari nilai alpha $(0,522>0,05)$. Tenaga kerja yang digunakan di Kelompok Tani Margo Utomo tidak berpengaruh disebabkan penggunaan yang cenderung tinggi sehingga akan berpengaruh terhadap pengeluaran biaya petani dan juga kualitas tenaga kerja yang perlu diperhatikan. Hal ini sesuai dengan pendapat Suryana (2007) yang menyatakan bahwa memperhitungkan tenaga kerja juga perlu dalam proses produksi, bukan hanya tentang tersedianya tenaga kerja saja tetapi kualitas dan kuantitas yang perlu diperhatikan.

Variabel benih berpengaruh nyata terhadap variabel produksi padi dengan nilai signifikan lebih kecil dari nilai alpha $(0,001<0,05)$ (Afidchao, Musters, Wossink, Balderama, \& de Snoo, 2014; Wang, Xue, Pan, Chen, \& Liu, 2018) Benih yang digunakan di Kelompok Tani Margo Utomo adalah bibit IR64 merupakan varietas unggul nasional. Benih merupakan faktor produksi yang berpengaruh besar setelah luas lahan terhadap produksi padi di Kelompok Tani Margo Utomo. Penggunaan benih yang sesuai dengan luas lahan, jarak tanam serta penggunaan benih yang berkualitas akan meningkatkan produksi padi. Hal ini sesuai dengan pendapat Yuliana et al. (2017) yang menyatakan bahwa penggunaan faktor produksi benih yang unggul meningkatkan kualitas dan kuantitas produksi sehingga berpengaruh terhadap produksi padi.

Variabel pupuk urea berpengaruh nyata terhadap variabel produksi padi dengan nilai signifikan lebih kecil dari nilai alpha $(0,004<0,05)$. Selain faktor produksi luas lahan dan benih, pupuk urea merupakan faktor produksi yang berpengaruh besar terhadap produksi padi di Kelompok Tani Margo Utomo. Pupuk urea mempunyai kontribusi yang besar dalam budidaya tanaman padi karna untuk memenuhi kebutuhan unsur hara. Pemberian pupuk urea sangat baik untuk budidaya tanaman padi karena pupuk urea mempunyai kandungan nitrogen yang bermanfaat untuk pertumbuhan akar, batang dan daun pada tanaman padi. Hal ini sesuai dengan pendapat Maharani et al. (2018) yang menyatakan bahwa pupuk urea mengandung nitrogen yang sangat membantu untuk pertumbuhan daun, batang dan akar pada tanaman padi.

Variabel pestisida berpengaruh tidak nyata terhadap variabel produksi padi dilihat dari nilai signifikansi yang lebih besar dari nilai alpha $(0,571>0,05)$. Penggunaan pestisida di Kelompok Tani Margo utomo cukup tinggi sehingga menyebabkan menurunnya produksi padi. Pemberian pestisida harus sesuai dosis yang telah diperhitungkan apabila berlebihan maka akan merugikan petani dan juga lingkungan sekitar. Hal ini sesuai dengan pendapat Yuliana et al. (2017) yang menyatakan bahwa menggunakan pestisida yang berlebihan akan berpengaruh negatif terhadap lingkungan yang ada disekitar.

Efisiensi Teknis dan Efisiensi Ekonomi. Pada usahatani, efesiensi teknis merupakan suatu hubungan keseimbangan antara jumlah penggunaan faktor-faktor produksi dengan jumlah hasil yang diperoleh. Analisis efisiensi teknis usahatani padi pada anggota Kelompok Tani Margo Utomo, Desa Kalikayen, Kecamatan Ungaran Timur, Kabupaten Semarang diperoleh dari nilai elastisitas produksi (b) yang berasal 
dari hasil output fungsi produksi model Cobb-Douglas. Efisiensi ekonomi merupakan suatu tingkat perbandingan antara keuntungan yang sebenarnya dengan keuntungan yang maksimum (Bhattacharya, 2017; Kaka, Shamsudin, Radam, \& Latif, 2016) Analisis efisiensi ekonomi ditinjau dari perbandingan antara nilai produk marginal (NPM) dengan biaya korban marginal (BKM), apabalia hasil perhitungan efisiensi ekonomi sama dengan 1 maka dikatakan efisien secara ekonomi, untuk lebih jelasnya efisiensi teknis dan efisiensi ekonomis dapa dilihat pada Tabel 4.

Tabel 3. Hasil Analisis Uji t

\begin{tabular}{lllll}
\hline No. & Variabel & Koefisien & t. Hitung & Sig. \\
\hline 1. & Konstanta & 1,645 & 4,050 & 0,000 \\
2. & Luas Lahan & 0,531 & 7,428 & $0,000^{* *}$ \\
$3 . \quad$ Tenaga Kerja & 0,046 & 0,645 & 0,522 \\
$4 . \quad$ Benih & 0,246 & 3,615 & $0,001^{* *}$ \\
$5 . \quad$ Pupuk Urea & 0,179 & 3,072 & $0,004^{* *}$ \\
$6 . \quad$ Pestisida & $-0,028$ & $-0,571$ & 0,571 \\
\hline $\begin{array}{l}\text { Sumber: Data Primer Penelitian, 2018. } \\
\text { Keterangan: } \\
* * \quad \text { signifikan }\end{array}$ & & & \\
\hline & & & \\
\hline
\end{tabular}

Tabel 4.Hasil Analisis Efisiensi Teknis dan Efisiensi Ekonomi

\begin{tabular}{lcc}
\hline Variabel & Efisiensi Teknis & Efisiensi Ekonomis \\
\hline Luas lahan (X1) & 0,531 & 3,404 \\
Tenaga kerja (X2) & 0,046 & 0,088 \\
Benih (X3) & 0,246 & 11,289 \\
Pupuk urea (X4) & 0,179 & 6,938 \\
Pestisida (X5) & $-0,028$ & $-2,640$ \\
\hline
\end{tabular}

Sumber: Data Primer Penelitian, 2018. 
Berdasarkan Tabel 4. didapatkan hasil analisis efisiensi teknis penggunaan faktor produksi luas lahan yaitu sebesar 0,531 dimana memiliki nilai yang berada dibawah satu maka dapat diartikan bahwa penggunaan faktor produksi luas lahan tidak efisien secara teknis. Nilai elastisitas produksi luas lahan sebesar 0,531 yang artinya apabila ada penambahan $1 \%$ luas lahan maka akan meningkatkan 0,531\% produksi padi dengan asumsi variabel lain bernilai tetap. Berdasarkan hasil analisis efisiensi ekonomi penggunaan faktor produksi luas lahan yaitu sebesar 3,404 dimana memiliki angka yang berada di atas angka satu maka dapat diartikan bahwa penggunaan faktor produksi luas lahan belum efisien secara ekonomi. Penggunaan faktor produksi luas lahan tidak efisiensi secara teknis dan belum efisiensi secara ekonomi, karena secara teknis faktor produksi luas lahan tidak perlu ditambahkan melainkan dikurangi penggunaannya sedangkan secara ekonomi faktor produksi luas lahan memiliki harga yang murah sehingga untuk mencapai efisien ekonomi sama dengan satu maka perlu tambahkan tapi tidak dengan meningkatkan penggunaannya.

Hasil analisis efisiensi teknis penggunaan faktor produksi tenaga kerja yaitu sebesar 0,046 dimana memiliki nilai yang berada dibawah satu maka dapat diartikan bahwa penggunaan faktor produksi tenaga kerja tidak efisien secara teknis. Nilai elastisitas produksi tenaga kerja sebesar 0,046 yang artinya apabila ada penambahan $1 \%$ tenaga kerja maka akan meningkatkan $0,046 \%$ produksi padi dengan asumsi variabel lain bernilai tetap. Berdasarkan hasil analisis efisiensi ekonomi penggunaan faktor produksi tenaga kerja yaitu sebesar 0,088 dimana memiliki angka yang berada di bawah angka satu maka dapat diartikan bahwa penggunaan faktor produksi tenaga kerja tidak efisien secara ekonomi. Penggunaan faktor produksi tenaga kerja tidak efisiensi secara teknis dan secara ekonomi, karena secara teknis penggunaan tenaga kerja yang berlebih dan berpengaruh negatif terhadap produksi padi sehingga mengharuskan mengurangi penggunaan sedangkan secara ekonomi penggunaan faktor produksi tenaga kerja yang berlebih membuat petani mengeluarkan biaya yang besar dalam proses produksi dan tidak sebanding dengan hasil produksi yang diperoleh.

Hasil analisis efisiensi teknis penggunaan faktor produksi benih yaitu sebesar 0,246 dimana memiliki nilai yang berada dibawah satu maka dapat diartikan bahwa penggunaan faktor produksi benih tidak efisien secara teknis. Nilai elastisitas produksi benih sebesar 0,246 yang artinya apabila ada penambahan $1 \%$ benih maka akan meningkatkan $0,246 \%$ produksi padi dengan asumsi variabel lain bernilai tetap. Berdasarkan hasil analisis efisiensi ekonomi penggunaan faktor produksi benih yaitu sebesar 11,289 dimana memiliki angka yang berada di atas angka satu maka dapat diartikan bahwa penggunaan faktor produksi benih belum efisien secara ekonomi. Penggunaan faktor produksi benih tidak efisiensi secara teknis dan belum efisiensi secara ekonomi, karena secara teknis faktor produksi benih tidak perlu ditambahkan melainkan dikurangi penggunaannya sedangkan secara ekonomi faktor produksi benih memiliki harga yang murah sehingga untuk mencapai efisien ekonomi sama dengan satu maka perlu tambahkan tapi tidak dengan meningkatkan penggunaannya.

Hasil analisis efisiensi teknis penggunaan faktor produksi pupuk urea yaitu sebesar 0,179 dimana memiliki nilai yang berada dibawah satu maka dapat diartikan bahwa penggunaan faktor produksi pupuk urea tidak efisien secara teknis. Nilai elastisitas produksi pupuk urea sebesar 0,179 yang artinya apabila ada penambahan $1 \%$ pupuk urea maka akan meningkatkan $0,179 \%$ produksi padi dengan asumsi variabel lain bernilai tetap. Berdasarkan hasil analisis efisiensi ekonomi penggunaan faktor produksi pupuk urea 
yaitu sebesar 6,938 dimana memiliki angka yang berada di atas angka satu maka dapat diartikan bahwa penggunaan faktor produksi pupuk urea belum efisien secara ekonomi. Penggunaan faktor produksi pupuk urea tidak efisiensi secara teknis dan belum efisiensi secara ekonomi, karena secara teknis faktor produksi pupuk urea tidak perlu ditambahkan melainkan dikurangi penggunaannya sedangkan secara ekonomi faktor produksi benih memiliki harga yang murah sehingga untuk mencapai efisien ekonomi sama dengan satu maka perlu tambahkan tapi tidak dengan meningkatkan penggunaannya.

Hasil analisis efisiensi teknis penggunaan faktor produksi pestisida yaitu sebesar $-0,028$ dimana memiliki nilai yang berada dibawah satu maka dapat diartikan bahwa penggunaan faktor produksi pestisida tidak efisien secara teknis. Nilai elastisitas produksi pestisida sebesar $-0,028$ yang artinya apabila ada penambahan $1 \%$ pestisida maka akan menurunkan 0,028\% produksi padi dengan asumsi variabel lain bernilai tetap. Berdasarkan hasil analisis efisiensi ekonomi penggunaan faktor produksi pestisida yaitu sebesar -2,64 dimana memiliki angka yang berada di bawah angka satu maka dapat diartikan bahwa penggunaan faktor produksi pestisida tidak efisien secara ekonomi. Penggunaan faktor produksi pestisida tidak efisiensi secara teknis dan secara ekonomi, karena secara teknis penggunaan pestisida yang berlebih dan berpengaruh negatif terhadap produksi padi sehingga mengharuskan mengurangi penggunaan sedangkan secara ekonomi penggunaan faktor produksi pestisida yang berlebih membuat petani mengeluarkan biaya yang besar dalam proses produksi dan tidak sebanding dengan hasil produksi yang diperoleh.

\section{KESIMPULAN DAN SARAN}

Kesimpulan. Faktor produksi luas lahan, tenaga kerja, benih, pupuk urea dan pestisida berpengaruh nyata secara serempak terhadap produksi padi. Faktor produksi yang berpengaruh nyata secara parsial terhadap produksi padi yaitu factor produksi luas lahan, benih dan pupuk urea. Faktor produksi tenaga kerja dan pestisida tidak berpengaruh terhadap produksi padi.

Hasil analisis efisiensi teknis penggunaan faktor produksi luas lahan, tenaga kerja, benih, pupuk urea dan pestisida tidak efisien secara teknis. Hasil analisis efisiensi ekonomi penggunaan faktor produksi luas lahan, benih, pupuk urea belum efisien secara ekonomi. Penggunaan faktor produksi tenaga kerja dan pestisida tidak efisien secara ekonomi.

Saran. Anggota Kelompok Tani Margo Utomo dapat menambahkan penggunaan faktor produksi luas lahan, benih dan pupuk urea agar produksi padi meningkat dan mengurangi penggunaan faktor produksi tenaga kerja dan pestisida karena dapat menambahkan produksi padi dan pendapatan petani serta agar efisiensi secara ekonomi tercapai.

\section{DAFTAR PUSTAKA}

Afidchao, M. M., Musters, C. J. M., Wossink, A., Balderama, O. F., \& de Snoo, G. R. (2014). Analysing the farm level economic impact of GM corn in the Philippines. NJAS - Wageningen Journal of Life Sciences, 70-71, 113-121.

Alamsyah, F. 2017. Analisis efisiensi teknis dan ekonomi penggunaan faktor-faktor produksi pada usahatani cabai keriting organik di Gapoktan Tranggulasi Desa Batur Kecamatan Getasan Kabupaten Semarang. Fakultas Peternakan dan Pertanian Universitas Diponegoro, Semarang. (Skripsi). 
Aprillya, M. R., Suryani, E., \& Dzulkarnain, A. (2019). System Dynamics Simulation Model to Increase Paddy Production for Food Security. Journal of Information Systems Engineering and Business Intelligence, 5(1), 67.

Badan Pusat Satistika. 2018. Kecamatan Ungaran dalam Angka 2018. Badan Pusat Statistika, Semarang.

Badan Pusat Statistika. 2017. Kecamatan Ungaran Timur dalam Angka 2017. Badan Pusat Statistika, Semarang.

Banerjee, A., \& Chaudhury, S. (2010). Statistics without tears: Populations and samples. Industrial Psychiatry Journal, 19(1), 60. https://doi.org/10.4103/0972-6748.77642

Baptista, A. T., Damanhuri, \& Nunun Barunawati. (2018). Characterization And Evaluation Of Appearance Rice (Oryza Sativa L.) Local East Timor And Rice Indonesia. Zenodo.

Basegmez, H., \& Onalan, O. (2018). Estimation of economic growth using Grey Cobb-Douglas production function: an application for US economy. Pressacademia, 7(2), 178-190.

Bashir, A., \& Yuliana, S. (2019). Identifying factors influencing rice production and consumption in Indonesia. Jurnal Ekonomi Pembangunan: Kajian Masalah Ekonomi Dan Pembangunan, $19(2)$.

Berndt, E. R., \& Christensen, L. R. (1973). The translog function and the substitution of equipment, structures, and labor in U.S. manufacturing 1929-68. Journal of Econometrics, 1(1), 81-113.

Bhattacharya, P. (2017). A Growth Framework Using the Constant Elasticity of Substitution Model. Journal of Applied Mathematics and Physics, 05(11), 2183-2195.

Ekowati, T., D. Sumarjono., H. Setiyawan., dan E. Prasetyo. 2014. Usahatani. PT UNDIP Press Semarang, Semarang.

Fitri, C. I., Mustafa, \& Azhar. (2018). EFFICIENCY ANALYSIS OF PRODUCTION FACTORS OF WETLAND PADDY FARMING IN WEST ACEH REGENCY. Russian Journal of Agricultural and Socio-Economic Sciences, 81(9), 424-428.

Huo, X., Wu, S., Zhu, Z., Liu, F., Fu, Y., Cai, H., ... Sun, C. (2017). NOG1 increases grain production in rice. Nature Communications, $8(1)$.

Indrasumunar, A., Searle, I., Lin, M.-H., Kereszt, A., Men, A., Carroll, B. J., \& Gresshoff, P. M. (2011). Nodulation factor receptor kinase $1 \alpha$ controls nodule organ number in soybean ( Glycine max L. Merr): Soybean nod factor receptor gene. The Plant Journal, 65(1), 39-50.

Kaka, Y., Shamsudin, M. N., Radam, A., \& Latif, I. A. (2016). Profit Efficiency among Paddy Farmers: A Cobb-Douglas Stochastic Frontier Production Function Analysis. Journal of Asian Scientific Research, 6(4), 66-75.

Kanianska, R. (2016). Agriculture and Its Impact on Land-Use, Environment, and Ecosystem Services. In A. Almusaed (Ed.), Landscape Ecology - The Influences of Land Use and Anthropogenic Impacts of Landscape Creation. 
Karmini, K. (2017). Factors affecting paddy farm income in East Kalimantan, Indonesia. Biodiversitas, Journal of Biological Diversity, 18(1), 101-108.

Khazanani, A. 2011. Analisis Efisiensi Penggunaan Faktor Faktor Produksi Usahatani Cabai Kabupaten Temanggung (Studi Kasus di Desa Gondosuli Kecamatan Bulu Kabupaten Temanggung). Fakultas Ekonomi dan Bisnis Universitas Diponegoro, Semarang. (Skripsi).

Kim, T. K. (2015). T test as a parametric statistic. Korean Journal of Anesthesiology, 68(6), 540.

Laghi-Pasini, F. (1977). [Action of the bromazepam-propantheline combination in patients with organic and functional gastrointestinal disorders]. La Clinica Terapeutica, 83(3), 301-311.

Liu, T., Bruins, R., \& Heberling, M. (2018). Factors Influencing Farmers' Adoption of Best Management Practices: A Review and Synthesis. Sustainability, 10(2), 432.

Maharani, A. D., E. Prasetyo, dan B. M. Setiawan. 2018. Analisis efisiensi ekonomi penggunaan faktor-faktor produksi pada usahatani padi di kelompok tani sidomakmur I Kecamatan Pati Kabupaten Pati. J. Ilmu-ilmu Pertanian. 2 (2): 1-17.

Meier, H., Eilola, K., \& Almroth, E. (2011). Climate-related changes in marine ecosystems simulated with a 3-dimensional coupled physical-biogeochemical model of the Baltic Sea. Climate Research, 48(1), 31-55.

Panel on Reengineering the Census Bureau's Annual Economic Surveys, Committee on National Statistics, Division of Behavioral and Social Sciences and Education, \& National Academies of Sciences, Engineering, and Medicine. (2018). Reengineering the Census Bureau's Annual Economic Surveys (K. G. Abraham, C. F. Citro, G. D. White, \& N. K. Kirkendall, eds.).

Peprah, M. S., \& Mensah, I. O. (2017). Performance evaluation of the Ordinary Least Square (OLS) and Total Least Square (TLS) in adjusting field data: an empirical study on a DGPS data. South African Journal of Geomatics, 6(1), 73.

Rahardja, D. (2017). A review of the multiple-sample tests for the continuous-data type. Journal of Modern Applied Statistical Methods, 16(1), 127-136.

Ramachandra Reddy, P., \& Kishori, B. (2019). Integrated Rice and Aquaculture Farming. In G. Diarte-Plata \& R. Escamilla-Montes (Eds.), Aquaculture - Plants and Invertebrates.

Suryana, S. 2007. Analisis Faktor-Faktor yang Mempengaruhi Produksi Jagung di Kabupaten Blora (Studi Kasus Produksi Jagung Hibrida di Kecamatan Banjarejo Kabupaten Blora). Program Pasca Sarjana Universitas Diponegoro, Semarang. (Tesis Magister Ekonomi).

Wang, L., Xue, C., Pan, X., Chen, F., \& Liu, Y. (2018). Application of Controlled-Release Urea Enhances Grain Yield and Nitrogen Use Efficiency in Irrigated Rice in the Yangtze River Basin, China. Frontiers in Plant Science, 9.

Yuliana, T. Ekowati, dan M. Handayani. 2017. Efisiensi Ekonomi Penggunaan Faktor Produksi pada Usahatani Padi di Kecamatan Wirosari Kabupaten Grobogan. J. AGRARIS. 3 (1): 1-19.

Zeigler, R. S., \& Barclay, A. (2008). The Relevance of Rice. Rice, 1(1), 3-10. 